\title{
The importance of interpersonal relationships in pre-school children to promote learning using the NAO Robot
}

\section{La importancia de las relaciones interpersonales en niños de nivel preescolar para favorecer el aprendizaje utilizando el Robot NAO}

\author{
APAN-ARAUJO, Karla Cecilia†*, MARTÍNEZ-TÉLLEZ, Rubelia Isaura, SORIANO-PORRAS, Dulce \\ Maria and HUESCA-LAZCANO, Erick Eduardo
}

Universidad Politécnica de Amozoc

ID $1^{\text {st }}$ Author: Karla Cecilia, Apan-Araujo / ORC ID: 0000-0003-3373-226X, Researcher ID Thomson: E-8338-2018, CVU CONACYT ID: 896703

ID $1^{\text {st }}$ Coauthor: Rubelia Isaura, Martínez-Téllez / ORC ID: 0000-0003-0164-066X, Researcher ID Thomson: E-82292018, arXiv Author ID: GYNFU8-XHIM03

ID $2^{\text {nd }}$ Coauthor: Dulce Maria, Soriano-Porras / ORC ID: 0000-0001-7398-0693, Researcher ID Thomson: E-8233-2018, arXiv Author ID: 8GO6IR-3HFFHH

ID $3^{\text {rd }}$ Coauthor: Erick Eduardo, Huesca-Lazcano / ORC ID: 0000-0002-0505-8442, Researcher ID Thomson: F-11622018, Open ID: 357590366000

DOI: 10.35429/JHEW.2019.4.3.6.12

Received March 05, 2019; Accepted June 30, 2019

\begin{abstract}
The present investigation forms part of the multiple options that can be worked with preschool children to favor their learning in each one of them, taking as a reference interpersonal relations and using the technology with the NAO Robot. In addition, it shows how to link teaching strategies, collaborative work, innovation and technology for the improvement of learning. To promote interpersonal relationships, a work plan was designed divided into three modules with certain planned activities, which were supported both by the teacher in charge of the group and the robot, it should be mentioned that the robot's programming was carried out by software engineering students from the Universidad Politécnica de Amozoc, Puebla. The general objective is to make a plan of activities using technology to promote interpersonal relationships in children and thus improve their learning. Interpersonal relationships are marked by an atmosphere of friendship, respect, understanding, listening and affection; aspects that undoubtedly increase the learning, self-esteem and sense of belonging of children.
\end{abstract}

Learning, Interpersonal relationships, NAO Robot

\begin{abstract}
Resumen
La presente investigación forma parte de las múltiples opciones que se pueden trabajar con los niños de nivel preescolar para favorecer su aprendizaje en cada uno de ellos; tomando como referencia las relaciones interpersonales y utilizando la tecnología con el Robot NAO. Además, se muestra la manera de vincular las estrategias docentes, el trabajo colaborativo, la innovación y la tecnología; para la mejora del aprendizaje. Para potenciar las relaciones interpersonales se diseñó un plan de trabajo dividido en tres módulos con determinadas actividades planificadas, las cuales fueron apoyadas tanto por la maestra a cargo del grupo y el robot, cabe mencionar que la programación del robot fue realizada por alumnos de Ingeniería en Software de la Universidad Politécnica de Amozoc, Puebla. El objetivo general es realizar un plan de actividades utilizando la tecnología para favorecer las relaciones interpersonales en los niños y así mejorar su aprendizaje. Las relaciones interpersonales están marcadas por un ambiente de amistad, respeto, comprensión, escucha y cariño; aspectos que, sin duda alguna aumentan los aprendizajes, la autoestima y el sentido de pertenencia de los niños.
\end{abstract}

Aprendizaje, Relaciones interpersonales, Robot NAO

Citation: APAN-ARAUJO, Karla Cecilia, MARTÍNEZ-TÉLLEZ, Rubelia Isaura, SORIANO-PORRAS, Dulce Maria and HUESCA-LAZCANO, Erick Eduardo. The importance of interpersonal relationships in pre-school children to promote learning using the NAO Robot. Journal Health, Education and Welfare. 2019. 3-4: 6-12

\footnotetext{
* Correspondence to Author (email: karla.apan@upamozoc.edu.mx)

$\dagger$ Researcher contributing as first author
} 


\section{Introduction}

Interpersonal relationships are of vital importance in all areas. In preschool can occur various difficulties due to the developmental characteristics of children of this age, in addition to the fact that these interpersonal relationships reach great value in the socio-emotional and cognitive development of children. Socialization at the preschool level allows children to choose their friends judiciously, create healthy friendships, overcome shyness, share with others, work in teams, etc. The human being is born to be sociable and develops socially relevant experiences; hence the importance of teaching children behavior patterns to maintain good relationships with others, which are the basis of good emotional intelligence and also influence their learning.

This research has as a general objective to generate activities using the NAO Robot to favor interpersonal relationships and improve learning in preschool children. The specific objectives are the following: a) To detect by means of a pretest the type of interpersonal relationships established in the group, b) Develop activities that strengthen interpersonal relationships in the group using the NAO Robot, c) Evaluate through a post test the use of the NAO Robot, through the results obtained from the development of the activities.

Therefore, with the help of a technological tool such as the NAO Robot of the Polytechnic University of Amozoc, Puebla, educational activities are generated in which students interact with said robot according to the activities planned by the teacher, generating new and better ways of working in teams, communication, delegating tasks and responsibilities, among other attitudes and useful skills that they will develop and strengthen during their time in school.

\section{Theoretical framework}

Some articles where robots have been used to improve interpersonal relationships using technology are briefly described below.

Advantages of NAO in any Educational Environment. In this article the authors mention that since 2009, there are more than 8000 NAO robots in the educational area and $80 \%$ of them are targeted at schools.
This reflects the high rate of implementation that the use of robots in general, as well as that of NAO in particular, is having in the elementary levels of education. On the other hand, it encourages curiosity and stimulates the interest of children in the classroom, regardless of the subject taught. NAO, with its 25 degrees of freedom of movement and its multiple sensors, can interact with children naturally and encourage them to work in groups through specific programs such as NER (NAO Entertainment Robot) V1.1. In this way, students are not only interested in robotics and learn how they work, but also attend classes taught by the robot. In the case of students, NAO motivates the learning process through its multiple sensors and its ability to communicate and interact with students. It becomes a link between theory and practice, since the robot explains the theory while executing it and shows itself as a practical example; in addition, the students program the robot themselves while witnessing the results. (Alive Robots, 2015).

Use of Educational Robotics as a Teaching Strategy in the Classroom. This article deals with a qualitative investigation of action research in the classroom, which proposes recreational activities with educational robots as a pillar of technology education, aiming to motivate students and educators to formulate and apply innovative educational strategy tools that use robotic platforms and technological devices that have concluded their useful life as a didactic instrument, so that the robot itself becomes a strategy within the classroom. In this way, it is sought to promote in preschool education students enthusiasm to develop skills that allow them to build knowledge and to give an informed, responsible and critical use of technology. Additionally, the teaching proposal involves students in recreational activities with educational robots to develop conceptualizations which allow them to address everyday problems related to the proper use of technology. (Barrier, 2014).

What Makes Robots Social?: A User's Perspective on Characteristics for Social Human-Robot Interaction. In this longitudinal study, it is mentioned how the field of robotics has rapidly advanced. There are different types of robots which are built and programmed to perform more and more difficult tasks to such an extent that they can become our assistants or guides and, in the not too distant future, our partners.

APAN-ARAUJO, Karla Cecilia, MARTÍNEZ-TÉLLEZ, Rubelia Isaura, SORIANO-PORRAS, Dulce Maria and HUESCA-LAZCANO, Erick Eduardo. The importance of interpersonal relationships in pre-school children to promote learning using the NAO Robot. Journal Health, Education and Welfare. 2019 
The robot used was Karotz and its interaction within the home influenced and improved social behaviors among its members. It is shaped like a rabbit connected to the internet, with a height of $30 \mathrm{~cm}$. The relationship occurs verbally, through the LED light on its belly, the movable ears, and by detecting the presence of other nearby objects. As Karotz is permanently connected to the internet, it is capable of reacting and transmitting all types of content available on its network, for example, news, messages, music, texts, alerts and radio. The built-in webcam allows users to communicate with family members at home for surveillance purposes when they are away. (Graaf, 2015).

Educational Robotics, a Tool for the Teaching-Learning of Sciences and Technologies. In this article, educational robotics is presented and analyzed as a support tool for the teaching-learning process, at a premedia level, mainly oriented to complex subjects such as Mathematics, Physics and Computer Science, among others. The study is limited to secondary schools in the Province of Chiriquí, Republic of Panama. A sample of six schools in the province was taken and, for each school, both students and teachers participated. The main objective of the project was to demonstrate how robotics applied to education, facilitating and motivating the teaching-learning of science and technology. The results showed that robotics can become an excellent tool to understand abstract and complex concepts in subjects related to the area of science and technology. It also allows developing basic skills, such as working in a team. (Moreno, 2012).

Robotics as a Resource to Facilitate Learning and Development of General Skills. The article mentions the growing importance of technology in the world and its continuous development, making technology in itself an integral part of the process of formation during childhood. For this reason, it is important to develop proposals that offer children and young people the possibility of coming into contact with new technologies. This is possible through the management of software and hardware tools, such as robotic prototypes and specialized programs for pedagogical purposes. It also shows the importance of the use of robotics as a learning tool and presents the typical stages that must be faced when implementing educational robotics projects in the classroom. (Bravo, 2012).

\section{Methodology}

In the development of practical work regarding the incorporation of the NAO Robot to favor interpersonal relationships through activities in a preschool group, a work plan was proposed, which was intended to provide consistent follow-up through guided activities, divided into two sessions, which start from a methodology using a technological strategy to enhance students' abilities, attitudes and aptitudes which are developed as follows:

Session 1. The activities that were carried out between the educator and the NAO Robot were based on the promotion of interpersonal relationships, considering two interventions at different dates.

On the first day, an activation routine directed by the robot was carried out. The next participation was based on a sequence of activities where the robot collaborated.

First intervention of the NAO Robot. The training class is called Physical Development and Health. The competence is to maintain control of movements that involve strength, speed and flexibility through games and exercise activities. The expected learning is to participate in games that make children identify and move different parts of their body. The didactic sequence was the presentation of a visitor in the classroom, knowing the name, age, origin and the purpose of the visit.

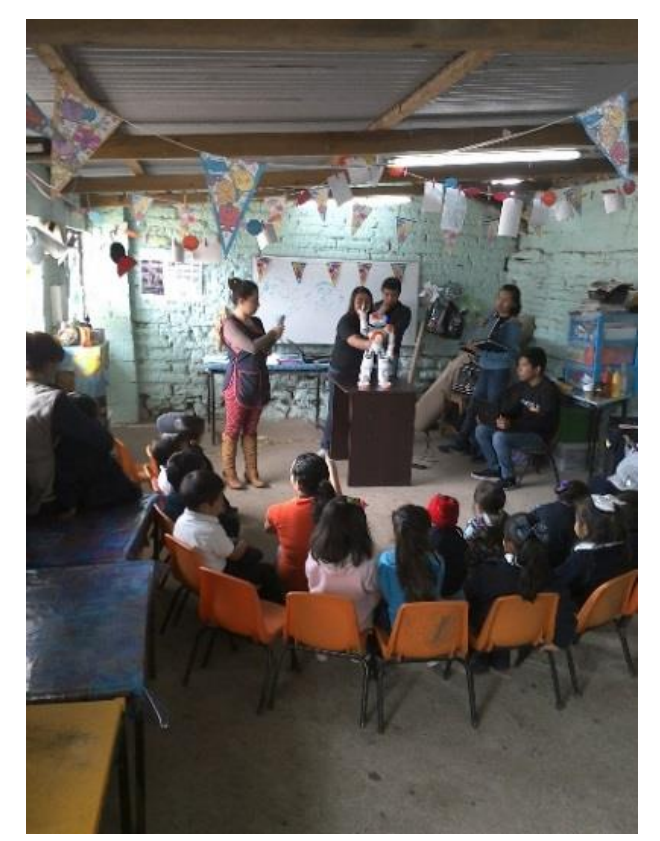

Figure 1 Presentation of the NAO Robot in the classroom Source: Prepared by the authors

APAN-ARAUJO, Karla Cecilia, MARTÍNEZ-TÉLLEZ, Rubelia Isaura, SORIANO-PORRAS, Dulce Maria and HUESCA-LAZCANO, Erick Eduardo. The importance of interpersonal relationships in pre-school children to promote learning using the NAO Robot. Journal Health, Education and Welfare. 2019 
Thus, the activity was developed as follows: The visitor and new friend invited to start the activation routine with a sequence of movements, such as moving the head both sides, raising and lowering the shoulders, bringing the arms to the sides, arms up and down, movement from the waist to the sides and in circles, alternating legs, kicking with alternating legs, jumps and finally breathing. It was completed by the new friend giving a present to each of the 23 students.

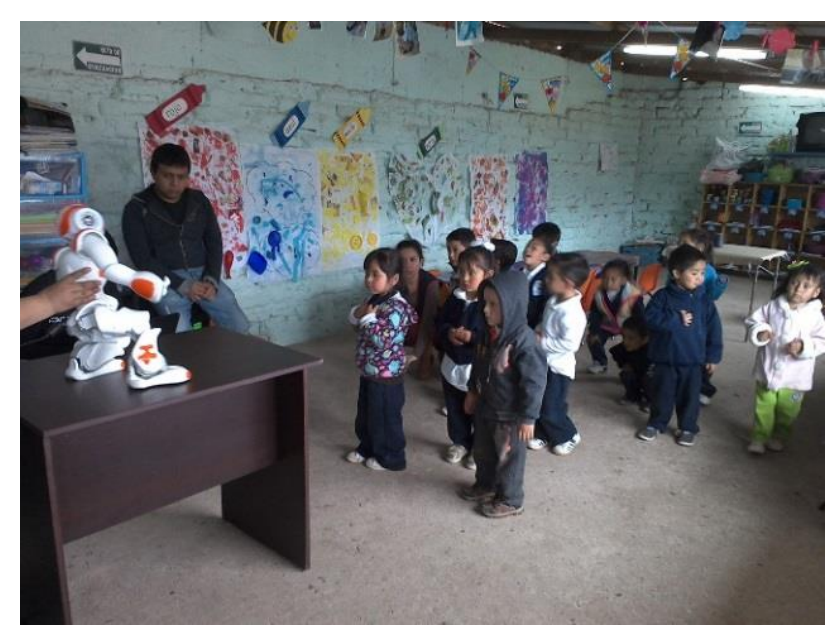

Figure 2 Physical activation routine led by the NAO Robot

Source: Prepared by the authors

Second intervention of the NAO Robot. The training class is called Personal and Social Development. The favored aspect is interpersonal relationships. The competence is to establish positive relationships with others, based on understanding, acceptance and empathy. The expected learning is to gradually accept the norms of relationship and behavior based on fairness and respect, and put them into practice.

The didactic sequence was divided into three moments. In the first one, the following activities were carried out: Greeting by NAO, activation routine directed by NAO, helping to remember the rules of the classroom, asking students to brainstorm and, with support of the teacher, writing the comments of the students on the board. The second moment consisted of NAO mentioning the importance of following the rules of the classroom, showing and mentioning the images that represented the action of each rule in the classroom.

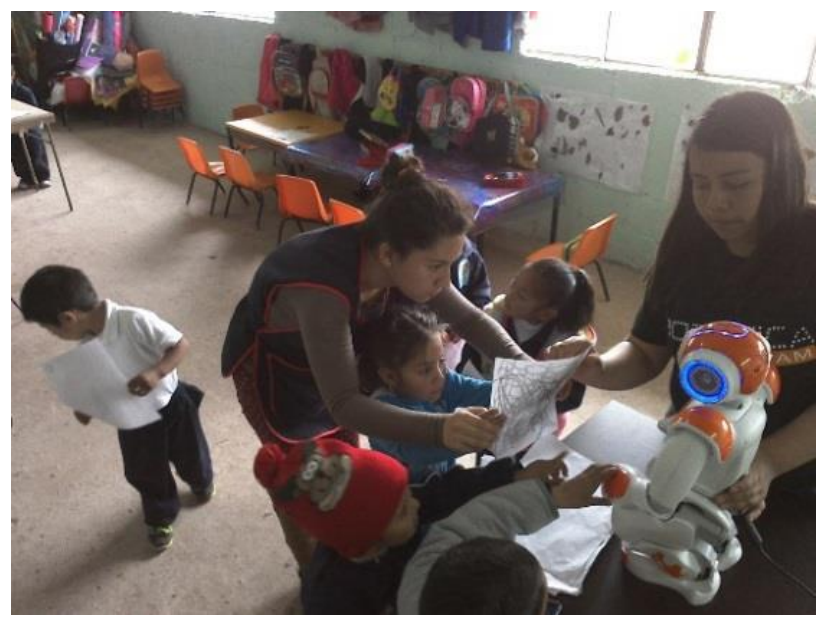

Figure 3 Importance of the classroom rules by the NAO Robot

Source: Prepared by the authors

The group was divided in teams according to the number of rules. NAO assigned to each student one of the rules, so that they monitored its compliance, and also provided material to each child to make badges according to the assigned rule. The last moment corresponded to the closure, which included the evaluation and farewell by the Robot.

NAO took out from a magic box different elements and classified them into two groups: one of them was for girls and the other for boys. Each group mentioned the elements that NAO assigned to each of them; the robot asked each group to explain each item and how it can help them be better classmates and friends. In the evaluation, NAO developed a plenary session with the students and the teacher reinforced what they learned on that day, providing recommendations to follow the rules. As for the farewell, NAO sang with the students a farewell song.

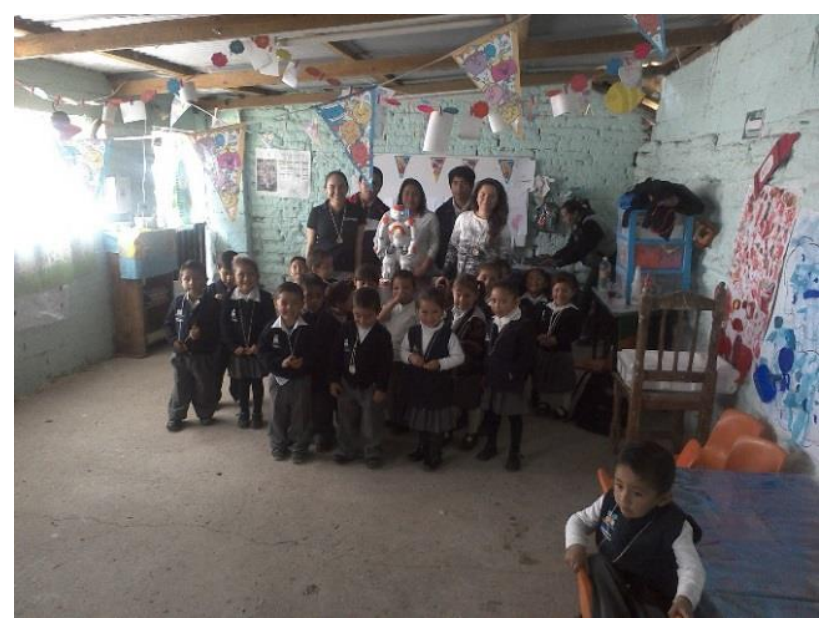

Figure 4 Farewell by the NAO Robot Source: Prepared by the authors 
Session 2. A software for the NAO Robot was designed with the Software Engineering students of the Polytechnic University of Amozoc to develop activities that would be implemented with the preschool group, in order to investigate the needs and applications in interpersonal relations, considering the two interventions.

In addition, tests were carried out at the Polytechnic University of Amozoc prior to the application of activities with the NAO Robot. In this section, the main activity was the application of activities designed with the NAO Robot and the educator (1st and 2 nd intervention).

It should be noted that in the programming tests for the second intervention, more movements were attached to the robot for physical activation, in addition to extensive dialogue so that the children paid more attention to the activities. A narrated story by the robot was also implemented to have greater interaction with the children.

Tests were also carried out where the robot mentioned the classroom rules and in the end asked the children to make a drawing. The tests consisted on the robot having to identify a logo on the edge of a sheet, which was subsequently delivered to each child in the classroom and so the robot could congratulate each child at the completion of the activity. These tests were carried out in three sessions so that the robot would identify them successfully.

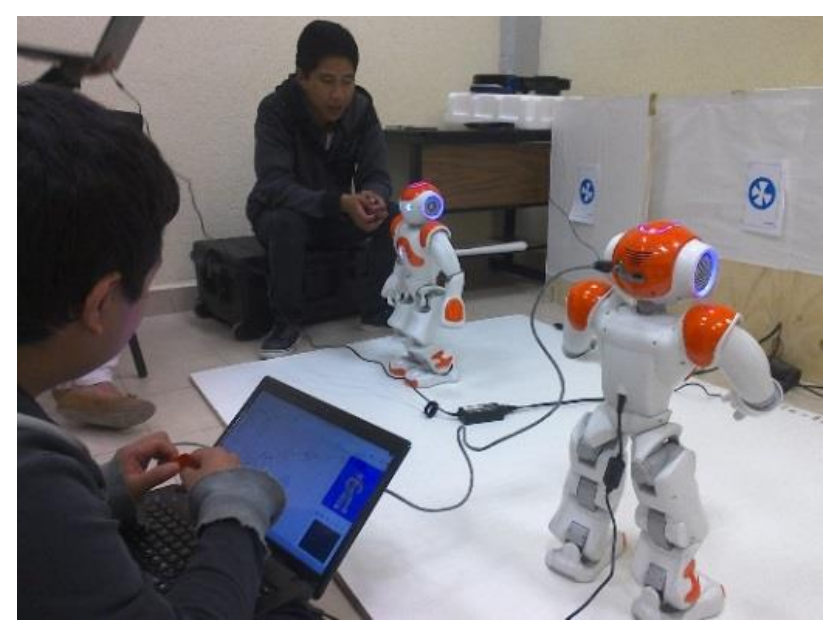

Figure 5 Software design and testing with the NAO Robot Source: Prepared by the authors

\section{Results}

To obtain quantitative results with respect to integration activities, two evaluations were carried out: one prior to the visit of the NAO Robot and a second after its intervention. Hence, the design of these activities was divided into two sessions based on the same elements of the current Preschool Program. The first intervention consisted on a greeting and presentation, activation routine and incentives provided by NAO in order to know the impact and reactions that it had on the students. The second NAO intervention consisted on a greeting, activation routine, presentation of school regulations, dynamics of collaboration between boys and girls, a plenary of what was learned, farewell and gifts.

In each evaluation, the children were asked to perform different activities as presented previously by the robot, as well as collaborative work done by the educator. The results of these activities during the first intervention applied to 23 children are shown in Table 1, where it can be observed that the social integration by the children improved.

\begin{tabular}{|l|c|c|c|c|}
\hline \multicolumn{5}{|c|}{ 1st. intervention } \\
\hline $\begin{array}{l}\text { They } \\
\text { do it }\end{array}$ & $\begin{array}{c}\text { They } \\
\text { do it } \\
\text { with } \\
\text { help }\end{array}$ & $\begin{array}{c}\text { They } \\
\text { have } \\
\text { difficulties }\end{array}$ & $\begin{array}{c}\text { They } \\
\text { do } \\
\text { not } \\
\text { do it }\end{array}$ \\
\hline $\begin{array}{l}\text { They accept their } \\
\text { classmates as they are and } \\
\text { understand that they have } \\
\text { the same rights as well as } \\
\text { responsibilities. }\end{array}$ & $20 \%$ & $40 \%$ & $20 \%$ & $20 \%$ \\
\hline $\begin{array}{l}\text { They understand that } \\
\text { people have different needs, } \\
\text { points of view, culture and } \\
\text { that they should be treated } \\
\text { with respect. }\end{array}$ & $50 \%$ & $20 \%$ & $15 \%$ & $15 \%$ \\
\hline $\begin{array}{l}\text { They learn about the } \\
\text { importance of friendship } \\
\text { and understand the value of } \\
\text { trust, honesty and mutual } \\
\text { support. }\end{array}$ & $50 \%$ & $15 \%$ & $20 \%$ & $15 \%$ \\
\hline $\begin{array}{l}\text { They internalize the rules of } \\
\text { relationship and behavior } \\
\text { based on fairness and } \\
\text { respect. }\end{array}$ & $40 \%$ & $30 \%$ & & \\
\hline $\begin{array}{l}\text { They become aware of } \\
\text { others and establish } \\
\text { communication and group } \\
\text { integration relations. }\end{array}$ & $30 \%$ & $50 \%$ & $15 \%$ & $15 \%$ \\
\hline $\begin{array}{l}\text { They establish attitudes and } \\
\text { relationships of respect and } \\
\text { collaboration. }\end{array}$ & $45 \%$ & $25 \%$ & $5 \%$ \\
\hline
\end{tabular}

Table 1 Activities during the 1st. Intervention Source: Prepared by the authors 
The results of these activities during the second intervention are shown in Table 2, where it can be observed that social integration improved even more, but also influenced attitudes and aptitudes not only individually, but also at the group level.

\begin{tabular}{|c|c|c|c|c|}
\hline \multicolumn{5}{|c|}{ 2nd intervention } \\
\hline & $\begin{array}{l}\text { They } \\
\text { do it }\end{array}$ & $\begin{array}{l}\text { They } \\
\text { do it } \\
\text { with } \\
\text { help }\end{array}$ & $\begin{array}{l}\text { They have } \\
\text { difficulties }\end{array}$ & $\begin{array}{c}\text { They } \\
\text { do } \\
\text { not } \\
\text { do it }\end{array}$ \\
\hline $\begin{array}{l}\text { They accept their } \\
\text { classmates as they are and } \\
\text { understand that they have } \\
\text { the same rights as well as } \\
\text { responsibilities. }\end{array}$ & $70 \%$ & $25 \%$ & $2.5 \%$ & $2.5 \%$ \\
\hline $\begin{array}{l}\text { They understand that } \\
\text { people have different needs, } \\
\text { points of view, culture and } \\
\text { that they should be treated } \\
\text { with respect. }\end{array}$ & $80 \%$ & $20 \%$ & $0 \%$ & $0 \%$ \\
\hline $\begin{array}{l}\text { They learn about the } \\
\text { importance of friendship } \\
\text { and understand the value of } \\
\text { trust, honesty and mutual } \\
\text { support. }\end{array}$ & $95 \%$ & $5 \%$ & $0 \%$ & $0 \%$ \\
\hline $\begin{array}{l}\text { They internalize the rules of } \\
\text { relationship and behavior } \\
\text { based on fairness and } \\
\text { respect. }\end{array}$ & $90 \%$ & $10 \%$ & $0 \%$ & $0 \%$ \\
\hline $\begin{array}{l}\text { They become aware of } \\
\text { others and establish } \\
\text { communication and group } \\
\text { integration relations. }\end{array}$ & $80 \%$ & $20 \%$ & $0 \%$ & $0 \%$ \\
\hline $\begin{array}{l}\text { They establish attitudes and } \\
\text { relationships of respect and } \\
\text { collaboration. }\end{array}$ & $90 \%$ & $10 \%$ & $0 \%$ & $0 \%$ \\
\hline
\end{tabular}

Table 2 Activities during the 2nd. Intervention Source: Prepared by the authors

\section{Conclusion}

This research showed how working with interpersonal relationships using technology, such as the NAO Robot, can help preschool students' learning. In addition, with the help of the intervention of the NAO Robot, these educational activities were adapted, which generated other ways of planning, organizing and changing attitudes and skills not so favorable in the classroom.

The attitudes and behaviors of the students were observed after the first intervention of educational activities, identifying gradual changes in the children. At the beginning of the final intervention, they were paying attention, following directions, listening and recording changes or results. With the development of the session with the NAO Robot, they reinforced and learned how to use the school rules and their benefits, as well as the development of empathy and values.
The next day, the students' attitudes were different, as they remembered the recommendations of the NAO Robot, in addition to presenting progress in their language development, oral and plastic productions like drawing, listening skills, respecting turns, among others, in reference to various training fields, such as exploration and knowledge of the world and physical development and health.

Therefore, we consider that this research contributed a scientific improvement in the educational area, since interpersonal relationships favor learning in preschool children and technology was also used.

Next, we present evidence of the work implemented to strengthen what was learned by the use of the NAO Robot to promote children's learning and generate and potentiate interpersonal relationships through certain activities.

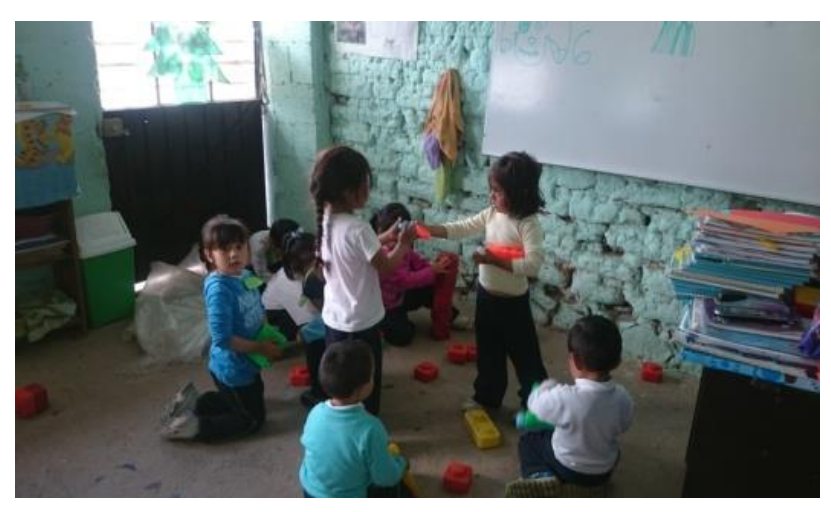

Figure 6 Materials selection

Source: Prepared by the authors

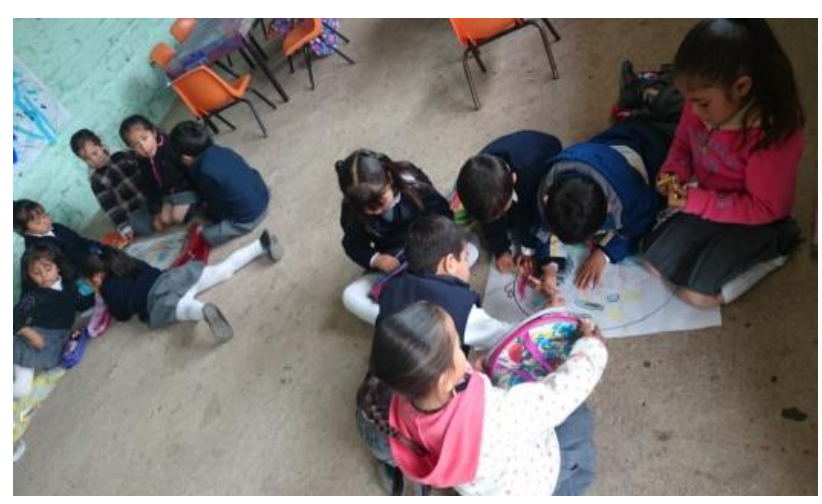

Figure 7 Construction of buildings with the help of my Friends

Source: Prepared by the authors 


\section{References}

Abarca, S. (2007). Psicología del niño en edad escolar. Costa Rica: EUNED. Retrieved from :https://books.google.es/books?id=PjnWBndw NJ8C\&pg=PA61 \&dq=piaget,+etapas+de+desar rollo+del+ni\%C3\%B1o\&hl=es\&sa $=X \&$ ei $=y 5 \mathrm{D}$ $\mathrm{uVOmuAeHas} A$ SImYDABw\&ved=0CCAQ6A EwAA\#v=onepage \&q=piaget $\% 2 \mathrm{C} \% 20$ etapas $\%$ 20de\%20desarrollo\%20del\%20ni\%C3\%B1o\&f $=$ false

Aguirre, P. (2012). Robótica y Mecatrónica Educativa. Retrieved from http://robmec.org/investigacion/proyectossemillas/robotica-y-mecatronica-educativa/, 2012.

Barrera, N. (2014). Uso de la robótica educativa como estrategia didáctica en el aula. Retrieved from

http://www.scielo.org.co/pdf/prasa/v6n11/v6n1 1a10.pdf

Bravo, F., Forero, A. (2012). La robótica como un recurso para facilitar el aprendizaje y desarrollo de competencias generales. Retrieved from

http://www.redalyc.org/pdf/2010/20102439000 7

Cedillo, J. (2010). NAO un francés en la robótica mexicana". Mexico City; Mexico. Retrieved from http://eleconomista.com.mx/tecnociencia/2011/ 10/25/nao-frances-robotica-mexicana

Dynamind. (2015). La robótica como una herramienta educativa. Retrieved from http://pequelia.es/104434/la-robotica-comouna-herramienta-educativa/

Flores, M. (2015). Creación de robots para apoyar el aprendizaje de niños con capacidades diferentes. Retrieved from http://sintesis.mx/articulos/66302/alumnos-dela-uth-disenan-robots-educativos/puebla

Graaf, A. (2015). What Makes Robots Social? A User's Perspective on Characteristics for Social Human-Robot Interaction. Proceedings of 7th International Conference, ICSR 2015, Paris, France, October 26-30, 2015, 184-193
Moreno, I. (2012). La robótica educativa, una herramienta para la enseñanza-aprendizaje de las ciencias y las tecnologías. Retrieved from http://www.redalyc.org/pdf/2010/20102439000 5.pdf 